\title{
Islamic Law Analysis of Criminal Sanctions for Abortion in the Criminal Code: A Call for Reform
}

\author{
Ishaq ${ }^{1}$, Maratun Saadah ${ }^{2}$ \\ ${ }^{1,2}$ Fakultas Syariah UIN Sulthan Thaha Syaifuddin Jambi \\ 1ishaqdama@gmail.com, ${ }^{2}$ saadahalfikri@gmail.com
}

\begin{abstract}
This study aims to contribute to Islamic law regarding the criminal sanction of abortion in the Criminal Code (KUHP) as an effort to reform Indonesian criminal law. The method used is comparison, with data collection carried out by library research, by studying Islamic legal literature, interpretation of the Quran (tafsir), hadith, Criminal Code, and the Draft of Criminal Code. The sanctions for abortion in articles 346, 347, 348 and 349 of the Criminal Code are only imprisonment, not accompanied by fines. According to Islamic law these sanctions are not sufficient, because they tend to make the perpetrators not deterred, as a result the purpose of punishment is not achieved. Therefore, it needs to be updated by including the value of Islamic legal sanctions in the form of fines (diat), so that the purpose of punishment can be achieved.
\end{abstract}

Keywords

Islamic Law, Abortion Crime, Criminal Code

Article Received: 10 August 2020, Revised: 25 October 2020, Accepted: 18 November 2020

\section{Introduction}

Abortion or feticide is an act that is prohibited by the Indonesian Criminal Code, as well as Islamic law. The act of abortion in the articles of the Indonesian Criminal Code is classified as a murder crime, which is regulated from Article 346 to Article 349 of the Criminal Code. These articles are listed in Chapter XIX Book II (two) entitled "Crimes Against People's Soul" (Soesilo, 2019). These articles which are applied in Indonesia today are a product of the colonial era, a derivative of the Wetboek van Strafrecht articles which came into effect on January 1, 1918 for all groups of the population (Ishaq, 2016). The enforcement of articles in the Criminal Code based on the transitional rules of Article II of the 1945 Constitution (Anwar, 2008), the original text is still in Dutch, except for later additions after 1946 which text has been translated into Indonesian, which style of translation depends on the taste of the translator (Hamzah, 2010), so that it cannot fulfill the aspirations and legal needs of the Indonesian nation. Therefore, to fulfill this legal need, it is necessary to reform the articles in the criminal law, especially the articles concerning the crime of abortion.

The crime of abortion continues to be a topic of discussion, regarding the pros and cons, as well as the findings of illegal abortion clinics in Indonesia. The Guttmacher Institute reported that there are 37 abortions in 1,000 (one thousand) reproductive age women aged 15 (fifteen) to 49 (forty-nine) years each year in Indonesia. This prediction figure tends to be quite high compared to abortion in other Asian countries. Of the 4.5 million births per year in Indonesia, around 760,000 or 17 percent were unwanted (Guttmacher Institute, 2008). Furthermore, according to the National Family Planning Coordinating Agency (BKKBN) report, there are approximately $2,000,000$ cases of abortion that occur every year in Indonesia. That means there are 2,000,000 lives who were brutally murdered every year without many knowing (Yusra, 2019). Hence, this data strengthens the argument that abortion punishment contained in the Criminal Code is not able to provide a deterrent effect to the abortion perpetrators.

Therefore, to provide a deterrent effect on abortion perpetrators, the sanctions for abortion in the upcoming Criminal Code should contain aspects of Islamic legal values, because the application of penalties in Islamic law aims to benefit human life, both spiritual and physical, individually and social. Benefit is not only for life in this world but also for eternal life in the hereafter (Ansori, Harahab, 2008).

The crime of abortion in Islamic law is an immoral act which results in the separation of the fetus from the mother (Muslich, 2005). Abortion 
in Islamic law is a type of a 'crime against life without justifiable reasons'. Imam Al-Gazali and Ibn Hajar Al-Haitsami argue that abortion is absolutely forbidden (Irfan, 2016). The perpetrator of an abortion must be sentenced to a very serious punishment with the aim of minimizing the occurrence of an abortion and deterring the criminal offender so that the act does not happen again (Nasution, 2013). Moreover, basically, the essence of punishment for perpetrators of an abortion according to Islam is the release of humans from all forms of damage (Syarifuddin, 2010).

Accordingly, based on the viewpoint of Islamic law, the sanctions for abortion as stated in the current article of the Criminal Code are not able to maintain order and the interests of society, and protect individual interests, so it is necessary to carry out reforms by incorporating Islamic legal values towards the abortion articles. Therefore, the authors is interested in discussing the analysis of Islamic law on criminal sanctions for abortion according to the Criminal Code as an effort to reform Indonesian criminal law.

\section{Methods}

Legal research in general can be categorized into doctrinal research and non-doctrinal research. Referring to the title and problem formulation, this research is included in the type of doctrinal research or normative legal research. Normative legal research or literature law research is legal research conducted by examining library materials consisting of primary legal materials, secondary legal materials, and tertiary legal materials (Soekanto, Mahmuji, 1985).

Legal research like this does not recognize field research because what it examines is legal materials so that it can be said as: library based, focusing on reading, and analysis of the primary and secondary materials. In the Dutch legal literature, the term normative legal research is known as the study of law (Ibrahim, 2006).

To discuss the problems, Author uses a comparative method, with data collection carried out by library research, by studying Islamic legal literature, alquranic tafsir, hadith, the Criminal
Code, and other scientific writings related to the subject matter (Ishaq, 2014).

\section{Results and Discussion}

\section{Abortion Sanctions in the Criminal Code and its elements}

In terms of etymology, the term abortion comes from the English word; miscarriage, termination, the action of bringing something or coming to an end. Whereas according to terminology is abortion (n); expulsion of fetus from the womb during the first 28 weeks of pregnancy (Hornby, Cowie, 1995). In legal terms, abortion means the removal of a conception from the uterus prematurely, before it can be born naturally (Islam, 1997). Abortion in the article of the Criminal Code is a material crime, for the perfection of the crime it is not enough to commit the act, but it is also a condition for the existence of the consequences of the act (Ishaq, 2016). There are several types of crimes of abortion in the Criminal Code article, namely:

1. Women or mothers themselves and / or order other people to cause the miscarriage or death of their womb (Article 346 of the Criminal Code)

2. Intentionally causing the miscarriage or death of a woman's womb without the woman's permission (Article 347 of the Criminal Code)

3. Intentionally causing the miscarriage or death of a woman's womb with the woman's consent (Article 348 of the Criminal Code)

4. A doctor, midwife or medicine man helps abortion crimes ( Article 349 of the Criminal Code)

Abortion as regulated in Article 346 of the Criminal Code, the sanction is imprisonment for a maximum of 4 (four) years with the elements that a woman causes her womb to be aborted, her womb dead; ordered someone else to cause the abortion, the womb death, on purpose. Causing the death of the womb means killing the womb in the mother's body. Aborting a child who is still in the womb is an act that results in a child who is still in the womb being born prematurely. It does not matter whether the child was born alive or dead as a result of the abortion, it must be done on a live womb (Anwar, 1994) 
Furthermore, Article 347 of the Criminal Code which states that 'intentionally causing the death or death of a woman's womb without the woman's permission, with the penalty being punishable by imprisonment of 12 (twelve) years, If the action causes the death of a woman, then the penalty is imprisoned for a maximum of 15 (fifteen) years, with the formula that the abortion was committed by another person not with the consent of the mother'. The formulation of Article 348 of the Criminal Code states that 'intentionally causing the death or death of a woman with the consent of the woman, the penalty is imprisonment for a maximum of 5 (five) years, if the woman dies, then the penalty is imprisoned for a maximum of 7 (seven) years. Whereas Article 349 of the Criminal Code states that the act of abortion is carried out by a doctor, midwife, traditional birth attendant or medicine specialist, the penalty is added by one third of the sanctions in articles 346, 437, and 348, and can also be fired from his position.

\section{Abortion Sanctions in Islamic Law and Its Elements}

The term abortion in Islamic law is known as isqat, ijhad, ilqa, taih, and inzal. The five words contain adjacent meanings, namely the abortion of the fetus from the womb before it reaches its perfection (Alwi, 2013). From the perspective of Sharia, the word "abortion" is known as the expression al-Ijhadh or Ishqat al-Haml, which means to distance, prevent (Ma'luf, 1973). Islamic context states that the life of the fetus (child in the womb) is a life that must be respected (Romli, 2011) by considering it as a living form that must be maintained. Therefore, in Islamic criminal law, abortion is known as a crime against a fetus or abortion occurs when there is an immoral act which results in the separation of the fetus from the mother (Suherman, 2004). Thus it can be understood that abortion in the view of Islamic law is a heinous act and is a crime. A crime which has complete elements and is committed by the perpetrator in a conscious and deliberate state will certainly be punished ${ }^{\mathrm{i}}$.

Aborting the womb after the fetus has been given life, all scholars of fiqh have agreed that it is forbidden and a post-mortem, which is not lawful for a Muslim to do. This is because the act is considered as the murder of a living person whose form has been perfect (Qardhawi, 1980). Furthermore, in the Islamic tradition, for example, states that human right to life is protected. Because, whoever the person has the right to enjoy life. Muhammad Abu Zahrah, the scholar of Ushul Fiqh stated that Islamic teachings are basically very concerned with maintaining five things, namely: religion, soul, mind, descent, and wealth (Zahrah, 1973), meanwhile abortion is an act that does not nourish the soul, even though it is a good deed to take care of the soul, therefore Allah is ordered to do it. On the other hand, anything that can remove or destroy a soul is a bad deed which Allah forbids. In this case, Allah forbids killing without rights, as explained in the Qur'an, surah al-'An'am (6) verse 151 which means:

Meaning: ... and do not kill a soul that is forbidden by Allah (to kill) but with something (cause) that is true ... (Q. Surat al-'An'am (6): 151) (Department of Religious Affairs, 2006)

According to the above verse, Islam provides a clear legal basis, that human life is sacred so that it must be preserved and the soul must not be removed unless it is done for a right reason, such as in execution of the death penalty, in war, and in self-defense justified by Sharia. Then the verse above also explains that killing is one of the biggest sins including abortion, because basically abortion includes the act of eliminating the life of a fetus that has already manifested itself, it includes murder.

It is further explained in al-qur'an, in Surah alIsra '(17) verse 33 which means: "and do not kill the soul that is forbidden by Allah (to kill), but with a (reason) that is correct, and whoever is killed in an wrongdoing, then indeed We have given power to the heirs, but the heirs do not go beyond the limit in killing. In fact he is a person who gets help "(Department of Religious Affairs, 2006).

The verse above explains that Allah forbids killing a human being, thus the right to life that is given by Allah for the life of a creature. It is clear here that the guarantee of life or human rights has been given by God to humans more than 13 centuries before people declared human rights. Therefore all Islamic legal literature from various 
mazhab agrees that abortion (fetal murder) is haram, because it is an act of torture and is absolutely not allowed (Nciri, 1993, as cited in Ibrahim, 1997), so that abortion is subject to sanctions, that is, according to the scholars, paying gurrah (male or female slave). This is explained in the hadith narrated by Muttafaq 'alaih, which means as follows:

From Abu Hurairah (May Allah be pleased with him), he said: Two women from the tribe of Hudzail fought, then one of the two threw stones at the other, then she killed him and killed the baby (fetus) that was in his stomach. They then complained about this to the Prophet Muhammad, then the Prophet decided that the diat for the fetus was a ghurrah (Hamka, 2007) ; male slave ('abd) or a female slave (amat) and the Prophet also decided that a diat for a woman (mother) should be given to her family (the killer) and inherited by her child and the person with her (her heir)... (Muttfaq alaih) (Al-Kahlani, 1960).

According to the hadith above, that the sanction imposed on abortion perpetrators is to pay diat if the fetus comes out alive and pay ghurrah if it comes out dead (Ummah, 2014). Ghurrah according to its original meaning is khiyar (choice). The servant of the slave is called a ghurrah because he is a choice treasure. In practice, this ghurrah (servant) is valued by five camels, or something equivalent, that is fifty dinars, or five hundred dirhams according to Hanafiyah, or six hundred dirhams according to the number of scholars (Muslich, 2005).

Meanwhile, the elements of abortion in Islamic law can be seen below, that are:

1. There is a clear passage forbidding

2. Behaviors that make up the acts of Jarimah, in the form of real actions, something that is not ordered by syara'.

3. There is a perpetrator of Jarimah.

In addition to the Jarimah elements of abortion as mentioned above, the classification of abortion is also explained as follows (Setiono, 2016);

1. Al-Ijhadah at-Tilqa'I or al-'Afwi (Abortion spontanea), which is a natural process by the uterus to issue a fetus that cannot be perfect for the elements of life in it. This kind of abortion can occur due to the large disability that befell him due to the pain of the mother who is suffering from various diseases such as diabetes.

2. Al-Ijhadhal-'Ilaji (Abortion Provokatus Medisinalis), which is an abortion that is deliberately performed by medics (doctors) in order to save the life of a mother, who in very rare circumstances that her pregnancy can continue safely

3. Al-Ijhadh al-Ijtima'I is also called al-Ijhadh alJina'i (Abortion Provokatus Kriminalis), namely abortion that is deliberately performed without any medical indication (illegal). The purpose of this abortion is not to give birth to a baby or to preserve appearance or cover up disgrace. Such abortion is prohibited by Islamic law, as well as in Indonesian criminal law

\section{Analysis of Islamic Law on Abortion Sanctions in the Criminal Code}

Religion plays a significant role in people decision to have an abortion as well as in a country's abortion law (Baker et al. 1981; Hertel and Hughes 1987; Schenker 2000; Hessini 2008; Padela et al. 2011). According to the view of Islamic law, the criminal sanctions for abortion as formulated in article 346, 347, 348, and 349 of the Criminal Code are relatively light and not accompanied by fines. This results in the perpetrator not deterring or afraid to commit the crime of abortion so that the purpose of the punishment is not achieved. As a result, the criminal sanctions stated in the articles of the Criminal Code concerning abortion do not function properly (Ishaq, 2012).

Therefore, it is necessary to transform the values of Islamic law in the formulation of criminal sanctions on abortion in the context of constructing thoughts on the abortion articles listed in the Criminal Code as an effort to reform Indonesian criminal law.

The criminal sanction for abortion perpetrators according to Islamic law as explained in the hadith of Abu Hurairah (Radhiyallahu Anhu) which was described by Muttafak 'alaih is a ghurrah (slave) whose value is five camels or the equivalent of fifty dinars or five hundred dirhams. In addition to paying gurrah, some fiqh scholars, including the Zahiri mazhab, state that abortion perpetrators are also subject to legal sanctions for 
kaffarat, that is liberating slaves and if they are unable to do so, then they must fast for 2 (two) consecutive months, and if they are still unable to do so, they must give food the poor 60 (sixty) people (Fatmawati, 2016). The imposition of criminal sanctions in Islamic law is to protect humans from damage to the soul. In line with this, Zainuddin Ali explained that the purpose of Islamic law is for the happiness of human life in the world and in the hereafter, by taking everything that is useful and preventing and rejecting everything that is not useful to human life (Ali, 2007). Furthermore, the essence of Islamic law is to care for humans, give full attention to humans and human dignity (Shiddieqy, 2001). Thus, the purpose of Islamic law is to determine the death penalty against murderers so that human rights to live and defend their lives are maintained. For this reason, Islamic law prohibits killing as an effort to eliminate the human soul and protect the various means used by humans to maintain the benefit of their lives (Mardani, 2010).

Abortion emerged as a phenomenon both among religious circles and law enforcers. Religious people view it as a moral violation because it takes away the right to life of humans. Meanwhile, according to law enforcers, abortion is considered a criminal act, because abortion is a real phenomenon even though this case in Indonesia is often covered up rather than being reported (Setiono, 2016). Apart from the sanctions mentioned above, there is also ta'zir punishment if the fetus is still alive or dies due to other reasons (Mustofa, Ahmad, 2013). If because of the perpetrator's act the fetus did not fall, or the mother died before the womb was released, or the fetus died after the mother died, then the punishment for the perpetrator in all these cases was ta'zir.

The abortion sanctions that are applied in Islamic law as described above are to correct and educate oneself not to commit similar crimes, as well as to provide an opportunity to recover as a good and harmless member of society (Rahman, 2020). A. Hanafi further explained that the punishment in Islamic criminal law has 3 (three) objectives, namely: (1) prevention (al-radd wa aljazr), (2) improvement (al-ishlah), (3) education ( $a l$-ta'dib) (Hanafi, 2005, as cited in Mardani, 2008) The aspect of prevention can be understood from the severity of punishment provided in Islamic law, thus deterring and fearing criminals from repeating their crimes. Meanwhile, other people who have the potential to commit crimes will think before doing it.

\section{Abortion Sanctions in Criminal Law Reform}

Criminal in the Criminal Justice System occupies a central position. This is because decisions in convictions will have broad consequences, both directly affecting the perpetrators of the crime and society at large (Priyantno, 2018). Reform of criminal law is only related to acts or norms formulated in law and its sanctions (Siahaan, 2016). The formulation of criminal sanctions on abortion in the reform of the criminal law has been explained in the articles of the 2019 Criminal Code draft, but the sanctions have not yet been included with fines. The abortion sanctions in the articles referred to are as follows;

Article 469, explains that the criminal sanction of abortion perpetrators by asking other people to be sentenced to imprisonment for a maximum of 4 (four) years, if the abortion is carried out without consent, then the maximum imprisonment is 12 (twelve) years. If the abortion results in the death of a woman, then the maximum imprisonment is 15 (fifteen) years.

Article 470, states that aborting a woman with her consent is punishable by a maximum imprisonment of 5 (five) years. If the abortion results in the death of a woman, then the maximum imprisonment is 8 (eight) years. Whereas Article 471 states that doctors, midwives, pharmacists who assist in committing the crime as referred to in Article 469 and Article 470 , the penalty can be added by $1 / 3$ (one third). Furthermore, doctors, midwives, paramedics, or pharmacists who commit the crime of abortion can be subject to additional punishment in the form of revocation of rights as referred to in Article 86, letters a and f (DPR RI, 2019).

Criminal sanctions are basically a means of protecting society and protecting individuals. Muladi explained that the purpose of punishment is to repair individual and social damages caused by criminal acts, this consists of a set of 
sentencing objectives that must be met, provided that which objectives are the emphasis of a case in nature (Muladi, 1985). Herbert L. Packer also explained that the purpose of punishment is to provide suffering to the perpetrators of crime and to prevent crimes. This can be seen from his writings, namely "In my view there are two and only two ultimate purposes to be served by criminal punishment: the reserved infliction of suffering on evil

doers and prevention of crime" (Packer, 1968).

One of the punishment objectives is prevention, that is why criminal law reform must also think about preventive aspects (Prasetyo, 2017) (Sambas, Mahmud, 2019)

The sanction of the criminal act of abortion as defined above according to Islamic law has not fulfilled the 'achievement of the goal' of punishment, because it only applies imprisonment. In its application, imprisonment sanctions are starting to reach a saturation point, because they do not reduce crime, and even more crimes. This is due to the fact that the implementation of the punitive approach through the prison system does not provide a satisfactory solution (Bakhri, 2016).

Therefore, the punishment of abortion in the articles of criminal law reform so that the sanctions can deter the perpetrators, it is necessary to include the values of Islamic legal sanctions in the form of fines, because the essential purpose of Islamic law is the benefit of humans and no law is mandated, either in the Koran. and Sunnah but in it there is benefit (Manan, 2006), even though Indonesia is not an Islamic state, but the majority of its population is Muslim, the value of religion is urgent (Al-Munawa, 20015), and its value is universal, so it deserves to be the source of the formation of national law.

In line with this, the position of Islamic law in national law is a sub-system of national law. Thus, the fines stated in the formulation of abortion crimes in Islamic law should be included in the formulation of sanctions in the articles of the Criminal Code which regulate abortion, so that the sanction of abortion in addition to imprisonment is also accompanied by fines in order to overcome the criminal act of abortion.
Fines are getting more and more attention to be researched, examined, in order to achieve the objectives of punishment in the community. This fine has been widely used by legislators in various legal products, laws and regional regulations. This is because criminal fines are a significant solution, and do not have an impact on the stigma of being a prisoner. In this case, a fine is a crime that brings goodness from a humanitarian perspective. Although he also felt his sorrow because he was obliged to pay a fine from his assets (Bakhri, 2016). Therefore, an action from the Government and legislators is needed to formulate these fines against abortion crimes as part of political criminal law activities that are rational and beneficial for justice.

It is further explained that efforts to reform Indonesian criminal law are certainly inseparable from legal politics whose task is to examines changes that need to be implemented to the law which in turn can meet new needs in society. In this case, according to Teguh Prasetyo, the proposed laws and regulations must be able to reflect the expected content of community values, (Prasetyo, 2017), such as the value of Islamic law. The politics of law provides a direction for the orderly development of law from the "ius constitutum" which is based on the framework of the previous legal foundation leading to the preparation of the "ius constituendum" or law to aspire to. Legal reform is more of a spirit in law, manifesting through the addition of a provision, the rule of law in law and statutory regulations, so that the law concerned becomes better, more useful and fair (Prasetyo, 2017).

Thus the authors recommend the formulation of criminal sanctions for abortion into the upcoming updates of the articles of the Criminal Code as follows;

\section{Article 469}

(1) Every woman who aborts or terminates her womb or asks someone else to abort or kill the womb shall be punished with imprisonment of up to 4 (four) years and a maximum fine of Rp.10,000,000 (ten million rupiah).

(2) Anyone who aborts or terminates a woman's womb without her consent shall be sentenced to imprisonment of up to 12 (twelve) years and a 
maximum fine of Rp. 200,000,000, - (two hundred million rupiah).

(3) If the act referred to in paragraph 2 results in the death of the woman shall be sentenced to imprisonment of up to 15 (fifteen) years and a maximum fine of Rp. 500,000,000, - (five hundred million rupiah)

Article 470

(1) Every person who aborts or terminates a woman's womb with her consent, shall be punished with imprisonment for a maximum of 5 (five) years and a maximum fine of $\mathrm{Rp}$. $10,000,000$ (ten million rupiah).

(2) If the act as referred to in paragraph (1) results in the death of the woman, the person shall be punished with imprisonment for a maximum of 8 (eight) years and a maximum fine of IDR $50,000,000$ (fifty million rupiah)

Article 471

(1) Doctors, midwives, paramedics, or pharmacists who help carry out the Crime as referred to in Article 469 and Article 470, the penalty can be added by $1 / 3$ (one third) and a maximum fine of Rp. 500,000,000 (five hundred million rupiah)

(2) (2) Doctors, midwives, paramedics, or pharmacists who commit a criminal act as referred to in paragraph (1) may be subject to additional punishment in the form of revocation of rights as referred to in Article 86 letters a and f, as well as a maximum fine of Rp. 60,000,000 (sixty million rupiah)

Criminal sanctions are basically a means of protecting society and protecting individuals. Muladi further explained that the purpose of punishment is to repair individual and social damages caused by criminal acts, this consists of a set of sentencing objectives that must be met, provided that which objectives are the emphasis of a case in nature (Muladi, 1985). Then Herbert L. Packer also explained that the purpose of punishment is to provide suffering to the perpetrators of crime and to prevent crimes. This can be seen from his writings, namely "In my view there are two and only two ultimate purposes to be served by criminal punishment: the reserved infliction of suffering on evil doers and prevention of crime" (Packer, 1968).

Teguh Prasetyo further explained that one of the objectives of punishment is prevention, then criminal law reform must also think about preventive aspects (Prasetyo, 2017). The same thing was also explained by Nandang Sambas, and Ade Mahmud, that punishment is a means of repairing the perpetrator of a criminal act and restoring the balance in the fractured social life order as a result of a criminal act and is not aimed at degrading human dignity (Sambas, Mahmud, 2019). This is a feature of criminal law reform

\section{Conclusion}

Abortion penalties in Articles 346, 347, 348, and 349 of the Criminal Code according to Islamic law are only imprisonment and are not accompanied by fines so as not to deter the perpetrator or fear committing the criminal act of abortion, as a result the purpose of the punishment is not achieved. Whereas the criminal sanctions for abortion in the view of Islamic law are in the form of qishash, and fines (diat). Imposing these sanctions in order to protect humans from damage to the soul, as well as to maintain human rights to live and defend their lives, so that the objectives of punishment are achieved, namely prevention (al-radd wa aljazr), improvement (al-ishlah), and education (al-ta'dib), so that the perpetrator is aware and deterred and afraid to repeat his crime again. Therefore, the formulation of sanctions for the crime of abortion needs to transform the values of Islamic law in the context of constructing thoughts on the abortion articles in the Criminal Code in an effort to reform Indonesian criminal law.

\section{References}

\section{Books}

[1] Al-Hijazi, M. M. (1992). Al-Tafsir alWadih, Vol. 2. Al-Zagazig, Egypt

[2] Al-Kahlani, M. B. I. (1960). Subul AsSalam Juz 3. Maktabah wa Mathba'ah Musthafa Al-Babiy Al-Halabi, Mesir, cet I.

[3] Al Munawar, S. A. H., \& Noer, H. M. (2004). Hukum Islam dan Pluralitas Sosial. Penamadani.

[4] Al Qaradhawi, Y. (1995). Fatwa-Fatwa Kontemporer 3. Jakarta: Gema Insani. 
[5] Ali, Z. (2007). Hukum Pidana Islam, Cet. I. Jakarta: Sinar Grafika.

[6] Anshori, A. G., \& Harahab, Y. (2008). Hukum Islam: dinamika dan perkembangannya di Indonesia. Total Media.

[7] Anwar, M. (1994). Hukum Pidana Bagian Khusus (Kuhp Buku II) Jilid I. Bandung: Citra Aditya Bakti.

[8] Anwar, Y. (2008). Pembaruan hukum pidana: Reformasi hukum. Jakarta: Grasindo.

[9] Ariman, H. R., \& Raghib, F. (2007). Hukum Pidana Indonesia. Universitas Sriwijaya, Palembang.

[10] Az-Zuhaily, W. (1989). Al-Fiqh al-Islami wa Adillatuhu, Juz IV. Beirut: Darul Fikri.

[11] Bakhri, S. (2016). Pidana denda: dinamikanya dalam hukum pidana dan praktek peradilan. Total Media.

[12] Ebrahim, A. F. M., \& Fadl, A. (1997). Aborsi, Kontrasepsi dan Mengatasi Kemandulan. Bandung: Mizan.

[13] Hamka, A. (1984). Tafsir al-Azhar, Jilid 10. Jakarta: Pustaka Panjimas.

[14] Hornby, A. S., \& Cowie, A. P. (1995). Oxford advanced learner's dictionary (Vol. 1430). Oxford: Oxford university press.

[15] Ibrahim, J. (2006). Teori dan metodologi penelitian hukum normatif. Malang: Bayumedia Publishing, 57.

[16] Indonesia, \& Soesilo (R.). (1976). Kitab undang-undang hukum pidana (KUHP): serta komentar-komentarnja lengkap pasal demi pasal. Bogor: politeia.

[17] Islam, D. R. E. H. (1997). Ensiklopedi Hukum Islam. Jakarta: PT. Ichtiar Van Hoeve.

[18] Mardani. (2008). Penyalahgunaan Narkoba dalam perspektif hukum Islam dan hukum pidana nasional. Rajawali Pers, Raja Grafindo Persada.

[19] Mardani. (2010). Hukum Islam: pengantar ilmu hukum Islam di Indonesia. Pustaka Pelajar
[20] Ma'luf, L. (1986). al-Munjid fi al-Lughah wa al-A'lam. Beirut: dar al-Masyriq.

[21] Muladi. (1985). Lembaga pidana bersyarat. Bandung: Alumni.

[22] Mustofa, H., \& Ahmad, S. B. (2013). Hukum Pidana Islam. Bandung: Pustaka Setia.

[23] Moeljatno, S. H. (2002). Asas-asas Hukum Pidana. Jakarta: Rineka Cipta.

[24] Nurul, I. (2016). Hukum Pidana Islam. Jakarta: Bumi Aksara.

[25] Packer, H. (1968). The limits of the criminal sanction. Stanford University Press.

[26] Priyatno, D. (2018). Bunga Rampai Pembaharuan Hukum Pidana Indonesia. Bandung: Pustaka Reka Cipta.

[27] Qardhawi, Y. (1993). Halal dan Haram dalam Islam, (H.Mu'amal, Trans.). Jakarta: Bina Ilmu.

[28] Rahman, A. (2002). penjelasan lengkap hukum-hukum Allah (Syariah). Jakarta: Raja Grafindo Persada.

[29] Saebani, M. H. D. B. A., \& Hasan, M. (2013). Hukum Pidana Islam Fiqh Jinayah. Bandung: Pustaka Setia.

[30] Sambas, N., \& Mahmud, A. (2019). Perkembangan Hukum Pidana. Bandung: Refika Aditama.

[31] Shiddieqy, M. H. A., \& Shiddieqy, F. H. A. (2001). Falsafah Hukum Islam. Semarang: Pustaka Rizki Putra.

[32] Shiddieqy, M. H. A. (2011). Tafsir alQur'anul Majid an-Nuur (Vol. 2). Jakarta: Cakrawala Publishing.

[33] Siahaan, M. (2016). Pembaruan hukum pidana Indonesia. PT. Grasindo.

[34] Suherman, A. M. (2004). Pengantar Perbandingan Sistem Hukum. Jakarta: Raja Grafindo Persada.

[35] Syarifuddin, A. (2010). Garis-Garis Besar Fiqh, cet. ke-3. Jakarta: Kencana prenada Media Group. 
[36] Syukri Albani Nasution, M. (2014). Filsafat Hukum Islam. Jakarta: Rajawali Pers.

[37] Soekanto, S., \& Mahmuji, S. (1985). Penelitian hukum normatif Suatu pengantar. Jakarta: Raja Grafindo Persada.

[38] Wardi, M. A. (2005). Hukum Pidana Islam. Jakarta: Sinar Grafika.

[39] Zahrah, M. A. (1973). Uṣ ūl al-fiqh. Dār al-Fikr al-' Arabī.

\section{Journals}

[40] Alwi, Z. (2013). Abortus Dalam Pandangan Hukum Islam. HUNAFA: Jurnal Studia Islamika, 10(2), 293-321

[41] Baker, R. K., Epstein, L. K., \& Forth, R. D. (1981). Matters of life and death: Social, political, and religious correlates of attitudes on abortion. American Politics Quarterly, 9(1), 89-102

[42] Fatmawati, F. (2016). Aborsi dalam Perspektif Hukum Islam (Meluruskan Problema Perempuan di Mata Publik). ALMAIYYAH: Media Transformasi Gender dalam Paradigma Sosial Keagamaan, 9(1), 151-163

[43] Hertel, B. R., \& Hughes, M. (1987). Religious affiliation, attendance, and support for "pro-family" issues in the United States. Social Forces, 65(3), 858882

[44] Hessini, L. (2008). Islam and abortion: The diversity of discourses and practices

[45] Ishak, I. (2012). Analisis Hukum Islam tentang Perbuatan Zina dalam Pasal 284 Kitab Undang-Undang Hukum Pidana dalam Pembaharuan Hukum Pidana. Kanun Jurnal Ilmu Hukum, 14(1), 165-178

[46] Ishaq, I. (2014). Kontribusi konsep jarimah zina dalam pembaharuan hukum pidana Indonesia. Ijtihad: Jurnal Wacana Hukum Islam dan Kemanusiaan, 14(1), 81-100
[47] Ishaq, I. (2016). Sanksi Pidana Pembunuhan Dalam Hukum Pidana Indonesia Dan Hukum Pidana Islam Sebagai Kontribusi Bagi Pembaruan Hukum Pidana Indonesia. AlRisalah, 16(1), 33-44

[48] Padela, A. I., Shanawani, H., \& Arozullah, A. (2011). Medical experts \& Islamic scholars deliberating over brain death: Gaps in the applied Islamic bioethics discourse. The Muslim World, 101(1), 5372

[49] Romli, D. (2011). Aborsi Dalam Perspektif Hukum Positif dan Hukum Islam (Suatu Kajian Komparatif). Al'Adalah, 10(2), 157-164

[50] Schenker, J. G. (2000). Women's reproductive health: monotheistic religious perspectives. International journal of gynecology \& obstetrics, 70(1), 77-86.

[51] Setiono, R. (2016). ABORTUS MENURUT HUKUM ISLAM DAN HUKUM POSITIF DI INDONESIA. LEX ET SOCIETATIS, 4(5)

[52] Ummah, S. C. (2014). Tindakan Aborsi Di Indonesia Menurut Hukum Islam. HUMANIKA, 14(1).

\section{Laws}

[53] Dewan Perwakilan Rakyat Rebublik Indonesia, Rancangan Undang-Undang Republik Indonesia Tentang Kitab Undang-Undang Hukum Pidana, (Jakarta : DPR-RI, 2019), hlm. 114 Websites

\section{Online News}

[1] Sushmita, Chelin Indra. (2020) solopos.com, Retrieved July 16, 2020, from https://www.solopos.com/ngeri-2juta-janin-diaborsi-di-indonesia-tiaptahun-1047436

\section{Report}

[1] Guttmacher Institute. (2008). R Retrieved July $\quad 16, \quad 2020, \quad$ from 
https://www.guttmacher.org/sites/default/fi les/report_pdf/aborsi_di_indonesia.pdf

${ }^{\text {i }}$ As quoted by Yusuf al-Qaradhawi from Ibn Hazm in his book al-Muhalla, he considers this act as a crime of deliberate murder which obliges the perpetrator to bear all risks, such as qishash law and so on. Yusuf Qaradhawi, Fatwa-Fatwa Kontemporer, Vol. 2 (Jakarta, Gema Insani, 1995), p. 772. 